Hoff, J., Cardol, M., Friele, R. Why does citizens' knowledge of new policy vary between municipalities? The case of the Social Support Act. Local Government Studies: 2013, 39(6), 816-)

\begin{tabular}{|l|l|}
\hline $\begin{array}{l}\text { Postprint } \\
\text { Version }\end{array}$ & 1.0 \\
\hline Journal website & http://www.tandfonline.com/doi/abs/10.1080/03003930.2012.755462 \\
\hline Pubmed link & \\
\hline DOI & $10.1080 / 03003930.2012 .755462$ \\
\hline
\end{tabular}

This is a NIVEL certified Post Print, more info at http://www.nivel.eu

\title{
Why Does Citizens’ Knowledge of New Policy Vary Between Municipalities? The Case of the Social Support Act
}

\author{
JELLE HOFF*, MIEKE CARDOL** AND ROLAND FRIELE** \\ *Policy Advisor and an independent researcher, \\ **Netherlands Institute for Health Services Research (NIVEL), Utrecht, the Netherlands
}

\begin{abstract}
Providing information to citizens is an important first step in the implementation of new policy. In this study we explain differences in the knowledge of citizens between municipalities of a newly introduced law in the Netherlands, the Social Support Act, 10 months after it became into force. This law is especially important for older people that need support in their daily functioning and participation. We focused on two aspects of knowledge related to the act, i.e. having heard of the new act, and knowing how voice with regard to policy on support is organised in the place of residence. Given that socialist local governments focus more on social topics than liberal local governments, we expected citizens of municipalities with socialist councils to have more knowledge about the new Social Support Act. Contrary to our expectations, citizens from municipalities where a liberal party or a collaboration of liberal/socialist parties is the largest, have a better understanding of how voice is organised. On the other hand, citizens in municipalities with an alderman from a combination of liberal/ socialist parties have a lower chance of having heard of the Social Support Act. We argue that in view of the Social Support Act, the ideology of a local government related to citizens’ responsibilities (liberal view) may have more influence on citizens' knowledge than being a government that pays attention to social issues (socialist view). As far as individual differences between citizens are concerned, as expected, older people that are more educated but in poorer health status have more knowledge about the new act. A higher educational level and an excellent mental health status are related to more knowledge about voice. Educational level is the most powerful predictor for knowledge about the act.
\end{abstract}


Hoff, J., Cardol, M., Friele, R. Why does citizens' knowledge of new policy vary between municipalities? The case of the Social Support Act. Local Government Studies: 2013, 39(6), 816-) 832

\section{INTRODUCTION}

\subsection{Background}

In the Netherlands, in January 2007 the Social Support Act (SSA; Wet maatschappelijke ondersteuning) (Tweede Kamer 2005/2006) was introduced. The aim of the SSA is participation of all citizens to all facets of society. This includes social participation, but also involvement in the policy of the municipality. The SSA 'forces' municipalities to involve citizens in the execution of the act. The introduction of citizen participation should increase accountability. Therefore, almost all municipalities have installed client councils that have the task to advice the municipality on policy developments, to signal problems in the execution of the act, and to formulate points for improvement. Municipalities now have the opportunity to develop a cohesive policy on social support, living and welfare along with other related matters. The SSA puts an end to various rules and regulations for handicapped people and the elderly. It encompasses the Services for the Disabled Act (WVG), the Social Welfare Act and parts of the Exceptional Medical Expenses Act (AWBZ). Box 1 gives an overview of the goals of the SSA. The SSA is part of the reconstruction of the Dutch welfare state and the changing role of the local government therein. It introduces a new scheme for all Dutch citizens covering care and support in cases of protracted illness, invalidity or geriatric diseases. Whereas support in the traditional Dutch welfare state used to be a right and variations in welfare and support were not tolerated, nowadays the government wants to provoke a change in the way of thinking of citizens. For example, the SSA is based on a hierarchy of support systems: if people need support, they first should try to solve this within their own social network. Informal family care is the first step when care is needed. And if the support provided by one's own network is not enough or not possible, people can turn to the local government for support. The underpinning of the SSA stems from the idea of a civil society, in which citizens take their responsibilities, care for each other and actively participate in all domains of life, including having a say in policymaking on a local level.

Municipalities have a large amount of freedom in developing policy, therefore making it possible to adapt policy according to the composition and demands of its inhabitants. Combining several laws and putting responsibility at the local level has been a recent trend in various countries such as Sweden (Trydega ${ }^{\circ}$ rd and Thorslund 2001).

The SSA decentralises responsibilities for public tasks that belong to the central government to the local level. There has been a large body of literature on decentralisation and the benefits and downsides associated with it. One of the most widely mentioned benefits is that the local government is better suited to meet local needs. Local governments are situated closer to its citizens and are therefore expected to be more perceptive of their needs and wishes and can adapt policy accordingly. To inform, consult and involve citizens in the development of local policy that affects these citizens can be seen as a justification for local government and a form of democratic renewal (Barnett 2011). One of the downsides, however, is the danger of lack of expertise, especially in smaller municipalities (De Vries 2000, Azfar et al. 2001, Bardhan 2002, Meijer 2007).

\section{[Box 1]}


Hoff, J., Cardol, M., Friele, R. Why does citizens' knowledge of new policy vary between municipalities? The case of the Social Support Act. Local Government Studies: 2013, 39(6), 816-) 832

The SSA may cause differences in policies related to social support between niver municipalities, but this is explicitly one of its intentions (Tweede Kamer 2004/2005). Studying and explaining these differences will be the focus of this study. With regard to the evaluation of laws, one important factor of interest is to determine whether the goals that the policy was designed for are achieved. However, this is dependent on the amount of time that the law has been in effect. If the evaluation is planned several years after the introduction, more effects are visible than when the evaluation is done after a short period of time (Klein Haarhuis and Niemeijer 2008). Because at the time of this study the SSA had been implemented only recently, this study is not an evaluation of the effects of the new law. Instead it will focus on one of the conditions for successful implementation of a law, i.e. the provision of information about the law to citizens.

Providing information to citizens can be a helpful tool in making a law a success. It can increase citizens' acceptance of the law, involvement and participation (Lando 1999, Cline 2000, Strobl and Bruce 2000, Lowndes et al. 2001). Moreover, research has found that more-informed citizens are more accepting of democratic norms such as political tolerance, are more efficacious about politics, are more likely to be interested in, follow and discuss politics, and are more likely to participate in politics in a variety of ways, including voting, working for a political party, and attending local community meetings. More informed citizens may even be 'better' citizens in a number of ways (Delli Carpini 1999). With the SSA the central government wants to make individuals more responsible for organising their own support, and this shift in responsibility means that knowledge of the SSA is even more important. In order to use services people must first know which services are available, but also how to apply for it. Politics is ultimately about 'who gets what' from government. With this in mind, the political significance of differences in knowledge is related to whether or not knowledge matters to effective citizenship (Delli Carpini 1999). Another important part of the SSA is the involvement of citizens in the development and appraisal of local social policy: voice. In Liverpool, voice of citizens in developing local policy was hindered by the fact that most people did not have enough foreknowledge and had to be introduced to the policy topic before they could actively participate (Lowndes e al. 2001).

Successful introduction of reflecting license plates for cars in Belgium was made more difficult because the government did not spend enough time informing the public about the purpose of these new license plates (Cline 2000).

This study will focus on the knowledge that people have of the SSA, and the differences between municipalities, on two levels. First, general knowledge of the SSA, defined by having heard of the law. This knowledge is important for citizens that need support for their participation. And secondly, a more specific type of knowledge is assessed, knowing how voice is organised in one's own municipality. This knowledge covers the other important participation aspect of the SSA; involvement of citizens in local policy. We will try to explain the differences between municipalities by studying structural as well as political characteristics. This study is innovative in that it goes beyond the individual factors and relates municipality characteristics to individual knowledge about an act that is executed at a local level. 
Hoff, J., Cardol, M., Friele, R. Why does citizens' knowledge of new policy vary between municipalities? The case of the Social Support Act. Local Government Studies: 2013, 39(6), 816832

\subsection{Structural and political characteristics}

The variation in needs of the local population and the adjustment of policy to fit those needs is one of the most widely used explanations for the variations in policy between municipalities. However, there is evidence that other factors are also involved. A range of studies has focused on certain structural municipal characteristics that explained differences between municipalities. For example, differences in individual services are better explainable by structural municipality factors than differences in collective services albeit that the correlations are relatively weak for both. Further, urbanisation is also a factor of influence, although contrary evidence exists on the precise direction of the effect (Sharpe and Newton 1984). For example, in Portugal, inhabitants of urbanised municipalities have access to better health services when compared to people living in rural areas (Santana 2000). The opposite can be said about the degree of urbanisation and home care services for elderly in Sweden. Sparsely populated municipalities provide better services than more densely populated municipalities (Trydega ${ }^{\circ} \mathrm{rd}$ and Thorslund 2001). This study will try to clarify the relationship between urbanisation and knowledge of the SSA. We expect that smaller, more rural municipalities are better aware of the needs of their citizens and will therefore be better able to inform their population than large urban municipalities. We also expect that when compared to large municipalities, citizens in smaller municipalities are more involved in local policymaking. This because of the lower complexity of the organisation of government and because citizens are situated closer to their government. Another factor that might have an influence is the presence of disadvantaged neighbourhoods within a municipality. The influence of this factor might be twofold. The presence of these neighbourhoods indicates that the target group for the SSA is large, which could mean more communication initiatives from the local government and therefore better informed citizens. However, it might also be that these neighbourhoods take up a distinctive amount of public funds so that less can be spend on providing information. With regard to involvement in policy, people from disadvantaged neighbourhoods tend to be less involved than those from better neighbourhoods (Huckfeldt 1979). Another way in which differences in policies between municipalities can be explained is to attribute them to political factors. In countries with a strong presence of social-democratic parties such as the Scandinavian countries, there is a much more developed welfare system than more liberal countries such as the United States (Miles and Quadagno 2002). Not only when comparing countries do politics have an influence, also which political parties are in power at the local level matters. In Norway, municipalities with more socialists in the council provide more services than municipalities with fewer socialists (Borge 2000). In general, municipalities with socialist parties in the city council spend more on social policy fields and also spend more in general, ask lower fees for services and have more city officials employed (Sharpe and Newton 1984, Borge 2000, Imbeau et al. 2001).

Although some Dutch studies have found no (Renaud and van Winden 1988) or contradicting (Denters 1987) support for these differences between socialist and liberal governments, other research in the Netherlands does supports this link between socialist governments and the spreading of tax pressure and spending on social policy fields (Coumans 1981, Giebels and Soons 1982, Allers et al. 2001, Wassenaar and van Soest 2002). The SSA is expected to have a substantial influence on the way social policy is organised in municipalities. Because socialist 
Hoff, J., Cardol, M., Friele, R. Why does citizens' knowledge of new policy vary between municipalities? The case of the Social Support Act. Local Government Studies: 2013, 39(6), 816-

governments focus more on social topics than liberal governments we expect that in municipalities where socialist parties are the largest parties, citizens will have more knowledge than municipalities where the largest party is liberal. Besides the influence that the local government has in general, the influence of the political background of the alderman that is responsible for the SSA has to be taken into account.

The alderman can make an effort to direct extra attention to the topic.

Because the alderman is directly responsible for the SSA whereas the largest party shares this responsibility with the other coalition parties, we expect that the alderman has more influence than the largest party. We expect aldermen from socialist parties to attach more importance to the SSA than aldermen from liberal parties. People who live in municipalities where a socialist alderman is responsible for the SSA will therefore have more knowledge of the SSA than those who live in municipalities with a liberal alderman.

To summarise, the central question of this study is whether there are differences in the amount of knowledge that citizens have of the SSA between municipalities, both in general terms of having heard of the SSA and more specific in knowing how voice is organised. Furthermore, we will study to what extent these differences can be explained by structural and political characteristics.

\section{MethodS}

\subsection{Survey sample}

Existing data was used from a mailed survey from October 2007 that was carried out among clients of a Dutch insurance company. These clients were part of a survey panel who are invited to participate twice a year.

Most panel-members live in the south of the Netherlands. Compared to the Dutch population, the panel consists of more elderly and people with another cultural background than Dutch are underrepresented. For this study people over 55 were included because the target group for the SSA is mostly elderly and disabled people. They are probably the first to be interested in the new act because they are more likely to be in need of support. Data was used from 4,501 respondents (response $87 \%$ ) consisting of $57 \%$ men and $42 \%$ women with a mean age of 69 (SD=7.7). As compared to all municipalities in the Netherlands, highly urbanised municipalities and low urbanised municipalities are underrepresented in this study.

\subsection{Dependent variables}

To assess participants' familiarity with the SSA and knowledge of voice, two questions were asked. Familiarity was measured by asking whether people had ever heard of the SSA. Three possible answers where provided, 'no', 'yes, sometimes' and 'yes, a lot'. The latter two were later combined to dichotomise the answers into 'yes' or 'no'. This first question measured knowledge on a relatively general level whereas the second question measured knowledge on a more specific level, although both questions measured subjective knowledge of the SSA. With the second question respondents were asked whether they knew how voice was organised in their own place of residence. This means that they had to have received specific information from their local government. Again, respondents could choose from three possible answers, 'no, no idea', 'I reasonably know it' and 'yes'. Dichotomisation was done by combining 'I reasonably know it' and 'yes'. 
Hoff, J., Cardol, M., Friele, R. Why does citizens' knowledge of new policy vary between municipalities? The case of the Social Support Act. Local Government Studies: 2013, 39(6), 816-) 832

\subsection{Individual-level covariates}

Age, sex, education, economic activity, income and general and mental health (Ware and Sherbourne 1992) were adjusted for in the analysis. These variables could be considered possible mediating or confounding factors in the relation between municipality characteristics and individual knowledge of its citizens. Table 1 presents an overview of the individual characteristics of the sample. Using the quartile values, the factor income was split into four categories.

\subsection{Municipality factors: structural characteristics}

Two structural characteristics were used to compare municipalities on.

Degree of urbanisation was measured on a scale from 1 (high urbanisation, i.e. 2,500 or more addresses per $\mathrm{km}^{2}$ ) to 5 (low urbanisation, i.e. fewer than 500 addresses per $\mathrm{km}^{2}$ ) according to the definition by the Central Bureau for Statistics (CBS).

The other structural characteristic used in this study was the presence or absence of disadvantaged neighbourhoods in a municipality. We used the definition as used by Wiegers and Deville' (2008) where a disadvantaged neighbourhood was defined by the number of inhabitants, number of addresses per $\mathrm{m}^{2}$, percentage non-Western immigrants, income data and percentage of those without jobs. An overview of both the structural and political characteristics can also be found in Table 1.

\subsection{Municipality factors: political characteristics}

To include political characteristics, two different measures were used: largest party in the governing coalition and alderman. In the Netherlands a large variety of parties take part in the political process. Because of the large number of parties that participate in the elections no party holds an absolute majority of the votes. To form an effective local government, several parties have to work together to form a coalition government. This means that unlike in the United States or United Kingdom where a single party is in charge and is able to implement policy according to its political views, in the Netherlands the policy that is introduced is often a compromise. It is therefore not possible to describe a coalition as typically socialist or liberal because it is made up out of several parties. We therefore use the largest party in the governing coalition of the municipality to describe whether the municipality can be characterised as liberal or socialist. This measure has a downside in that it provides a somewhat simplistic view of a municipality. It can be possible that two parties have almost the same amount of votes, but only the largest party is used to define the place of the municipality in the political spectrum. Using information on municipal websites on the most recent elections (2006), an overview of the largest party of each municipality could be obtained. On the municipal level, local parties also play a major role. These parties form a category of their own since each specific local party exists only in a single municipality. Alongside the parties that also take part in the national elections, a category 'local party' was added.

\section{[TABLE 1]}

Furthermore, when using the definitions to classify the political parties as described, a small number of municipalities could not be classified. In these municipalities a combination of parties formed the largest party in the government. That is, different parties had formed a union with other parties. 
Hoff, J., Cardol, M., Friele, R. Why does citizens' knowledge of new policy vary between municipalities? The case of the Social Support Act. Local Government Studies: 2013, 39(6), 816-
832

Most of the time these parties included liberals (D66) together with several combinations of socialist parties. We named this distinct category the 'liberal/socialists'.

The municipal websites were also used to define the political background of the alderman responsible for the SSA. This information was used in the analyses.

\subsection{Statistical analyses}

Because of the hierarchical structure of the data, comprising two levels of analysis the citizen and municipality level - analyses were based on a multi-level approach using MLwiN software. This method also presents the advantage of allowing decomposition of variance of each dependent variable in order to determine the proportion of variability attributable to each level. A logistic model was adopted in view of the dichotomous nature of the dependent variables analysed.

First, we estimated a model with no explanatory variables and described the variance in percentage of citizens that had heard of the SSA and the percentage that knew how voice was organised. Then the explanatory variables (individual characteristics, structural and political factors) are added to the model. The significance of the variables is described with odds ratios (OR). The odds ratio is a measure of effectsize, described as the ratio of the odds of an event occurring in one group to the odds of it occurring in another group. The values of the odds ration lie between zero (maximum of negative association) and+infinite (maximum of positive association), whereas no association provides an odds ratio that equals 1 . Because we use a logistic model, one category of the independent variable is used as a reference to compare the other categories with. We chose the Christian democrats (CDA), which can be characterised as conservative as a reference category.

\section{RESULTS}

\subsection{Individual factors}

Individual factors play an important role in the amount of knowledge people have of the SSA. In general, women, people older than 74 years of age, those with a higher educational level, a higher income (€1900-2500) and those with a poor general health status more often had heard of the SSA (Table 2). This is according to our expectations as people with a poor general health status are those most affected by the SSA. People with a higher educational level and those with an excellent mental health status more often claim to know how voice is organised in their municipality. People with a poor mental health status more often claim that they did not know how voice is organised (Table 3).

\section{[TABLE 2]}

\subsection{Familiarity with Social Support Act: differences between municipalities}

Participants were asked whether they had ever heard of the SSA; responses were almost evenly split: $57 \%$ of the respondents indicated that they had heard of the act, whereas $43 \%$ indicated that they had not. Without controlling for any individual or municipal factors, the percentages of having heard of the SSA range from $52 \%$ of the population to $6 \% \%$ between municipalities.

Table 2 presents the odds ratios for the individual, structural and political characteristics for having heard of the SSA. The structural characteristics, degree of 
Hoff, J., Cardol, M., Friele, R. Why does citizens' knowledge of new policy vary between municipalities? The case of the Social Support Act. Local Government Studies: 2013, 39(6), 816-

urbanisation and the presence of a disadvantaged neighbourhood are not significant. With regard to political factors, the political colour of the largest party does not have a significant influence. Which party provides the alderman, however, does have a significant influence. When compared to the citizens in municipalities where a conservative (CDA) aldermen is responsible for the SSA, citizens in municipalities with an alderman from one of the liberal/socialist parties have lower chance of having heard of the SSA (OR=0.51; Confidence Interval $(\mathrm{CI})=0.32-0.84)$. When controlled for all background characteristics, the percentage of people that has heard of the SSA ranges between 27 and 36. This means that with the indicators chosen we could explain $25 \%$ of the variance between citizens in having heard of the SSA.

\subsection{Voice in Social Support Act: differences between municipalities}

More differences can be found with regard to knowing how voice is organised in the municipality: $25 \%$ of participants indicated that they knew how voice was organised whereas $75 \%$ indicated that they did not know.

Without controlling for individual or municipality characteristics, large differences between municipalities were found. The percentages of knowing how voice is organised range from $19 \%$ of the population to $31 \%$.

Table 3 presents the odds ratios for the knowledge on how voice is organised in the SSA. Again none of the structural factors is significant.

Contrary to familiarity with the SSA, the largest party does have an influence whereas the alderman has no significant effect on knowledge of voice. When compared to municipalities where the conservatives (CDA) are the largest party, people in municipalities where the largest party is liberal/ socialist have a higher change of knowing how voice is organised (OR=2.39; $\mathrm{CI}=1.47-3.88)$. The same effect is found in municipalities where the liberals (VVD) are the largest party $(\mathrm{OR}=2.09$; $\mathrm{CI}=1.01-4.33)$ and where the local part is the largest party $(\mathrm{OR}=1.39$; $\mathrm{CI}=1.00-1.94)$.

This means that citizens from municipalities where a local party, the liberal party or a collaboration of liberal/socialist parties is the largest, have a better understanding of how voice is organised than citizens from municipalities where the largest party is a conservative one (CDA).

When controlled for political and structural differences between municipalities, the percentage of people that has heard of the Social Support Act ranges between 9 and $18 \%$, which means that with the indicators in the model we could explain about $12 \%$ of the variation in knowing how voice is organised.

\section{[TABLE 3]}

\section{DISCUSSION}

Differences exist in the level of self-reported knowledge that people older than 55 years of age have about the SSA, 10 months after it came into force.

This was shown with regard to familiarity with the SSA (SGBO 2007) and also when people with disabilities were asked about their knowledge of the SSA (Marangos et al. 2008). In this study we examined associations between two measures of knowledge of the SSA and several characteristics of municipalities. Three main observations arise. First, knowledge of the SSA differs largely between citizens. 
Hoff, J., Cardol, M., Friele, R. Why does citizens' knowledge of new policy vary between municipalities? The case of the Social Support Act. Local Government Studies: 2013, 39(6), 816-) 832

Second, individual-level factors appear to be the best means of explaining differences in knowledge levels. Third, political factors had a minor influence whereas the structural factors we defined in this study had no significant influence. Maybe also remarkable is that differences between municipalities emerged in a short period of time, less than one year, after the introduction of the law.

\subsection{Measures of knowledge}

One distinct finding is the difference in percentages of citizens that have heard about the SSA as compared to the percentage of citizens that knows how voice is organised. This may be because having heard of the act is a very general way of measuring knowledge, whereas knowing how voice is organised is more specific and requires more accurate knowledge of the SSA related to one's place of residence. Another explanation is related to differences in sources of information. General knowledge about the SSA could have come from national sources, such as the national government and mainstream media. Information on how voice is organised according to the SSA had to come from local sources since the regulations may differ between municipalities. Understanding how voice is organised can therefore be seen more as a result of efforts from the municipality.

\subsection{Individual level}

The influences of municipality factors in the differences in knowledge of the SSA are relatively small. It can be concluded that individual background has a larger impact on amount of knowledge than the municipal characteristics.

Educational level is a crucial factor for both familiarity with and understanding of voice in the SSA. When compared to those with none or only primary education, people with a higher educational level are both more familiar with the SSA

$(\mathrm{OR}=4.60 ; \mathrm{CI}=3.28-6.46)$ and have more knowledge of voice $(\mathrm{OR}=4.27 ; \mathrm{CI}=2.72-$ 6.72).

\subsection{Structural vs. political factors}

Both the degree of urbanisation and the presence of disadvantaged neighbourhoods had no significant influence on knowledge of the SSA and knowledge of how voice is organised. Only in two instances did a political factor have an effect. When the alderman belonged to one of the combination of liberal/socialist parties, fewer citizens had heard of the SSA.

Also in municipalities with a liberal/socialist party, the liberal party or a local party being the largest party, people had better understanding of how voice is organised than in municipalities with conservatives (CDA) being the largest party. These findings were not according to our expectations, although the fact that citizens from municipalities with a large local party more often know how voice is organised may be because local parties are indeed better suited to meet local needs. However, we expected that citizens from municipalities with large socialist parties and socialist aldermen would score better on both general and specific knowledge of the SSA. There might be two explanations for this discrepancy, however. Firstly, the VVD and D66 both embrace a liberal ideology. Previous research has mostly focused on the differences between left- and right-wing parties (Sharpe and Newton 1984, Borge 2000, Imbeau et al. 2001, Trydega ${ }^{\circ}$ rd and Thorslund 2001, Miles and Quadagno 2002, Wassenaar and van Soest 2002). Parties who see themselves as part of the liberal ideology focus more on involving citizens in designing policy than parties from other political backgrounds (Torpe and Nielsen 2004). This may explain why 
Hoff, J., Cardol, M., Friele, R. Why does citizens' knowledge of new policy vary between municipalities? The case of the Social Support Act. Local Government Studies: 2013, 39(6), 816-
832

the significant effect of the liberal party (VVD) related to voice was found, as compared to the Christian democrats that can be characterised as conservatives. There might be another effect as well. The basis of the SSA lies within citizens' own responsibility to arrange their own support if necessary and less involvement of governments. Liberal parties support the withdrawal of government activities in peoples' lives. The importance of decentralised decision-making and the value of the freedom of choice, assuming the capacity and desire of citizens to be self-reliant are characteristics of a liberal society (Stewart 1993). Because liberal parties are more positive about the goal of the new law they might have promoted it more than parties that are less enthusiastic, such as the Christian democrats.

\subsection{Methodological considerations}

Several considerations have to be made when interpreting the results of this study. First of all, existing data was used in this study and the dependent variables measure only a small aspect of knowledge about a new act. Also the respondents in this study came from 82 municipalities, whereas the Netherlands has about 400 municipalities. Moreover, as compared to all municipalities in the Netherlands, highly urbanised municipalities and low urbanised municipalities are underrepresented in this study. It is not exactly known how this influenced the results of the study, although the degree of urbanisation did not show a significant relation with knowledge about the SSA. Initially, we wanted to include more structural municipality characteristics than the two that were eventually used in this study.

However, in order to have results that where robust enough to be meaningful, highly correlated and conceptually similar factors were removed.

Furthermore, the questionnaires were sent only 10 months after the introduction of the SSA. From evaluations of the law, it became clear that most municipalities were still busy with the implementation of the law in the first year after the introduction (van Houten et al. 2008). This focus on implementation has probably had a negative effect on the effort of providing information. Perhaps different results could be found if the questionnaires were done after a longer period of time.

Finally, it should be stressed that the measurement in this study did not include objective political knowledge, rather a measure of self-reported knowledge was used. It is therefore unknown whether the respondents who claimed to have heard of the SSA or said to know how voice was organised really had actual political knowledge. On the other hand, the expected effect discussed in the paper pertain to subjective competence rather than actual knowledge, and for these expectations the used measure is quite well suited.

\section{CONCLUSION}

Early after the introduction of the SSA, differences between municipalities can be observed. Our results show that 10 months after the law came into force, municipal factors have a small influence on individual levels of selfreported knowledge with regard to the new law. Individual characteristics of citizens are more influential. Especially the educational level of citizens is of influence with regard to both kinds of knowledge about the new act.

Contrary to our expectations, liberal parties, or a combination of liberal/ socialist parties, and the local parties had a significant influence with regard to the knowledge of citizens about how voice is organised. Citizens in municipalities with an alderman from one of the liberal/socialist parties less often had heard of the SSA. We argue 
Hoff, J., Cardol, M., Friele, R. Why does citizens' knowledge of new policy vary between municipalities? The case of the Social Support Act. Local Government Studies: 2013, 39(6), 816-)

that in view of the SSA, the ideology of a local government related to citizens' responsibilities (liberal view) may be a factor of more importance than being a government that pays attention to social issues (socialist view).

\section{Notes on contributors}

Jelle Hoff is a Policy Advisor at the regional government, the Provincie Zuid-Holland, and part-time student of healthcare policy, innovation and management atMaastricht University. Before that he was a research student at NIVEL, the Netherlands Institute for Health Services Research. His research interests include public, youth care and healthcare policy.

Roland D. Friele is Professor at Tilburg University and deputy director of NIVEL, the Netherlands Institute for Health Services Research. He joined NIVEL in 1989, and as a researcher in the field of psychiatric epidemiology he gradually moved his attention from the role of the individual in health care towards governance issues. He now studies the societal impact of health care legislation.

Mieke Cardol is a Senior Researcher at NIVEL, the Netherlands institute for health services research, and Associate Professor at Rotterdam University of Applied Sciences. Her research interest involves the social and societal participation of people with disabilities and the broad array of factors that may be of influence on their participation. Recent publication: M. Kroneman, M. Cardol, and R. Friele, '(De)centralization of social support in six Western European countries', (Health Policy, 106 (1), 2012.

\section{REFERENCES}

Allers, M., de Haan, J., and Sterks, C., 2001. Partisan influence on the local tax burden in the Netherlands. Public Choice, 106 (3-4), 351-363.

Azfar, O., Ka"hko" nen, S., and Meagher, P., 2001. Conditions for effective decentralized governance: a synthesis of research findings. College Park, MD: IRIS Centre.

Bardhan, P., 2002. Decentralization of governance and development. The Journal of Economic Perspectives, 16 (4), 185-205.

Barnett, N., 2011. Local government at the nexus? Local Government Studies, 37 (3), 275290.

Borge, L.E., 2000. Charging for public services: the case of utilities in Norwegian local governments. Regional Science and Urban Economics, 30 (6), 703-718.

Cline, K.D., 2000. Defining the implementation problem: organizational management versus cooperation. Government Information Quarterly, 22, 374-388.

Coumans, P.A.H.H., 1981. Gemeentelijk inkomsten- en reinigingsbeleid: Verslag van een vergelijkend Onderzoek. Enschede: University of Twente.

De Vries, M.S., 2000. The rise and fall of decentralization: a comparative analysis of arguments and practices in European countries. European Journal of Political Research, 38 (2), 193-224.

Delli Carpini, M., 1999. In search of the informed voter: what Americans know about politics and why it matters. Paper presented at conference on The Transformation of Civic Life, Middle Tennessee State University, America, 12-13 November 1999.

Denters, S.A.H., 1987. Partijen, kiezers en gemeentelijk beleid: een empirische toetsing van een politiek-economische theorie. Amsterdam: CT Press.

Giebels, R. and Soons, J.L.G.M., 1982. Verschillen in uitgaven tussen gemeenten: Een verklaringsmodel. Amsterdam: SEO.

Huckfeldt, R.R., 1979. Political participation and the neighborhood social context. American Journal of Political Science, 23 (3), 579-592.

Imbeau, L.M., Pe' try, F., and Lamari, M., 2001. Left-right party ideology and government policies: a meta-analysis. European Journal of Political Research, 40 (1), 1-29.

Klein Haarhuis, C.M. and Niemeijer, E., 2008. Wet en Werkelijkheid: Bevindingen uit Evaluaties van Wetten. The Hague: WODC.

Lando, T., 1999. Public participation in local governments: points of view. National Civic Review, 88 (2), 109-122. 
Hoff, J., Cardol, M., Friele, R. Why does citizens' knowledge of new policy vary between municipalities? The case of the Social Support Act. Local Government Studies: 2013, 39(6), 816-)

Lowndes, V., Pratchett, L., and Stoker, G., 2001. Trends in public participation: part 2 citizens' perspectives. Public Administration, 79 (2), 445-455.

Marangos, A.M., Cardol, M., and de Klerk, M., 2008. Ondersteuning en Participatie van Mensen met een Lichamelijke Beperking. Utrecht: NIVEL.

Meijer, A.J., 2007. Publishing public performance results on the internet: do stakeholders use the internet to hold Dutch public service organizations to account? Government Information Quarterly, 24 (1), 165-185.

Miles, J. and Quadagno, J., 2002. Political theories of the welfare state. Social Service Review, 76 (1), 34-57.

Renaud, P. and van Winden, F., 1988. Fiscal behaviour and the growth of government in the Netherlands. In: J. Lybeck, and M. Henrekson, eds. Explaining the growth of government. Amsterdam: North Holland, pp. 133-156.

Santana, P., 2000. Ageing in Portugal: regional iniquities in health and health care. Social Science and Medicine, 50, 1025-1036.

SGBO, 2007. Tevredenheid Clie"nten Social Support Act. The Hague: SGBO.

Sharpe, L.J. and Newton, K., 1984. Does politics matter? Oxford: Oxford University Press. Stewart, J., 1993. Rational choice theory, public policy and the liberal state. Policy Sciences, 26 (4), 317-330.

Strobl, J. and Bruce, N., 2000. Achieving wider participation in strategic health planning: experience from the consultation phase of Liverpool's 'City Health Plan'. Health Promotion International, 15, 215-225.

Torpe, L. and Nielsen, W., 2004. Digital communication between local authorities and citizens in Denmark. Local Government Studies, 30 (2), 230-244.

Trydega ${ }^{\circ}$ rd, G.B. and Thorslund, M., 2001. Inequality in the welfare state? Local variation in care of the elderly - the case of Sweden. International Journal of Social Welfare, 10, 174184.

Tweede Kamer, 2004/2005. Nieuwe regels betreffende maatschappelijke ondersteuning (Wet maatschappelijke ondersteuning); Memorie van Toelichting, Tweede Kamer, vergaderjaar 2004/2005, 30131, nr. 3.

Tweede Kamer, 2005/2006. Wet van 29 juni 2006, houdende nieuwe regels betreffende maatschappelijke ondersteuning (Wet maatschappelijke ondersteuning), Tweede Kamer, vergaderjaar 2005/2006, 351.

Van Houten, G., Tuyman, M., and Gilsing, R., 2008. De invoering van de SSA: gemeentelijk beleid in 2007. The Hague: Sociaal en Cultureel Planbureau.

Ware, J.E. and Sherbourne, C.D., 1992. The MOS 36-item short-form health survey (SF36). I.

Conceptual framework and item selection. Medical Care, 30 (6), 473-483.

Wassenaar, M.C. and van Soest, D.P., 2002. Local fiscal strategies in the Netherlands: an empirical analyses. Local Government Studies, 28 (2), 88-100.

Wiegers, T.A. and Deville' , W., 2008. Herijking Stedelijke Achterstandsgebieden 2008. Utrecht: NIVEL. 
Hoff, J., Cardol, M., Friele, R. Why does citizens' knowledge of new policy vary between municipalities? The case of the Social Support Act. Local Government Studies: 2013, 39(6), 816-) 832

\section{BOX AND TABLES}

Box 1. Goals of the Social Support Act

- Participation of all citizens to all facets of society including having a say in local policy (further: voice).

- Development of a cohesive policy on social support, living and welfare along with other related matters.

- Increase of social cohesion.

- Provision of tailor-made services and support.

- Reduction of costs for exceptional medical expenses. 
Hoff, J., Cardol, M., Friele, R. Why does citizens' knowledge of new policy vary between 832 municipalities? The case of the Social Support Act. Local Government Studies: 2013, 39(6), 816-

Table 1. Characteristics of the study population and the municipalities included in the study

\begin{tabular}{|c|c|c|}
\hline \multicolumn{2}{|l|}{ Individual characteristics } & 4501 \\
\hline \multicolumn{2}{|l|}{ Mean age (SD) } & $68.8(7.7)$ \\
\hline \multirow[t]{3}{*}{ Gender } & Men & $56.9 \%(2,561)$ \\
\hline & Women & $42.1 \%(1,894)$ \\
\hline & Missing & $1.0 \%(46)$ \\
\hline \multirow[t]{3}{*}{ Education } & None/primary & $9.6 \%(348)$ \\
\hline & Secondary & $67.1 \%(2,425)$ \\
\hline & University & $23.3 \%(842)$ \\
\hline \multirow[t]{3}{*}{ Employment } & Employed & $10.2 \%(395)$ \\
\hline & Unemployed & $14.2 \%(549)$ \\
\hline & Retired & $75.6 \%(2,930)$ \\
\hline \multirow[t]{4}{*}{ Income } & $<€ 1400$ & $31.0 \%(1,037)$ \\
\hline & $€ 1400-€ 1900$ & $28.3(947)$ \\
\hline & $€ 1900-€ 2500$ & $26.2(878)$ \\
\hline & $>€ 2500$ & $14.5(487)$ \\
\hline \multirow[t]{3}{*}{ General health } & Excellent & $18.9 \%(743)$ \\
\hline & Good & $55.0 \%(2,172)$ \\
\hline & Poor & $26.1(1,034)$ \\
\hline \multirow[t]{3}{*}{ Mental health } & Excellent & $47.1 \%(1,866)$ \\
\hline & Good & $47.1 \%(1,865)$ \\
\hline & Poor & $5.8 \%(229)$ \\
\hline \multicolumn{2}{|c|}{ Municipality characteristics (n) } & 82 \\
\hline \multicolumn{3}{|c|}{ Structural factors } \\
\hline \multirow{2}{*}{$\begin{array}{l}\text { Disadvantaged } \\
\text { neighbourhoods }\end{array}$} & No & $93.4 \%$ \\
\hline & Yes & $6.6 \%$ \\
\hline \multirow{5}{*}{$\begin{array}{l}\text { Degree of } \\
\text { urbanisation }\end{array}$} & 1 (High urbanisation) & $1.6 \%(74)$ \\
\hline & 2 & $46.0 \%(2,069)$ \\
\hline & 3 & $22.0 \%(993)$ \\
\hline & 4 & $24.3 \%(1,093)$ \\
\hline & 5 (Low urbanisation) & $6.0 \%(272)$ \\
\hline \multicolumn{3}{|l|}{ Political factors } \\
\hline \multirow{6}{*}{$\begin{array}{l}\text { Largest party } \% \text { of } \\
\text { respondents (number } \\
\text { of municipalities) }\end{array}$} & Social democrats/socialist (PvdA) & $53.7 \%$ (24 municipalities) \\
\hline & Christian democrats/conservative (CDA) & $15.0 \%$ (22 municipalities) \\
\hline & Liberals/liberal (VVD) & $1.5 \%$ ( 2 municipalities) \\
\hline & Socialists/socialist (SP) & $4.5 \%$ (3 municipalities) \\
\hline & Local party & $20.8 \%$ (24 municipalities) \\
\hline & Liberal/socialist & $4.4 \%$ ( 7 municipalities) \\
\hline \multirow{6}{*}{$\begin{array}{l}\text { Alderman } \% \text { of } \\
\text { respondents (number } \\
\text { of municipalities) }\end{array}$} & Social democrats/socialist (PvdA) & $31.6 \%$ (29 municipalities) \\
\hline & Christian democrats/conservative (CDA) & $17.0 \%$ (18 municipalities) \\
\hline & Green party/socialist (GroenLinks) & $17.3 \%$ (6 municipalities) \\
\hline & Socialists/socialist (SP) & $21.9 \%$ ( 8 municipalities) \\
\hline & Local party & $8.0 \%$ (14 municipalities) \\
\hline & Liberal/socialist & $4.2 \%$ (6 municipalities) \\
\hline
\end{tabular}


Hoff, J., Cardol, M., Friele, R. Why does citizens' knowledge of new policy vary between municipalities? The case of the Social Support Act. Local Government Studies: 2013, 39(6), 816832

Table 2. Individual and municipal characteristics in relation to familiarity with the Social Support Act (odds ratios ( $95 \%$ confidence intervals); multivariate, multi-level regression models)

\begin{tabular}{|c|c|c|c|}
\hline \multicolumn{4}{|c|}{ Have you heard of the Social Support Act? } \\
\hline $\begin{array}{l}\text { Participant } \\
\text { characteristics }\end{array}$ & Odds ratios & $\begin{array}{c}\text { Municipality } \\
\text { characteristics: } \\
\text { Structural factors }\end{array}$ & $\begin{array}{l}\text { Odds } \\
\text { ratios }\end{array}$ \\
\hline Gender & \multicolumn{3}{|c|}{ Disadvantaged neighbourhoods } \\
\hline Men & 1.00 & No & 1.00 \\
\hline Women & $1.21(1.03-1.44)^{*}$ & Yes & $1.02(0.74-1.42)$ \\
\hline Age & & \multicolumn{2}{|l|}{ Degree of urbanisation } \\
\hline $5-63$ & 1.00 & 1 (high urbanisation) & $0.56(0.28-1.11)$ \\
\hline $64-68$ & $1.13(0.86-1.48)$ & 2 & $0.82(0.63-1.08)$ \\
\hline $69-74$ & $1.20(0.90-1.60)$ & 3 & 1.00 \\
\hline$>74$ & $1.39(1.03-1.86)^{*}$ & 4 & $1.10(0.83-1.44)$ \\
\hline Education & & 5 (low urbanisation) & $1.01(0.69-1.48)$ \\
\hline None/primary & 1.00 & & \\
\hline Secondary & $2.23(1.69-2.94)^{*}$ & \multirow{2}{*}{\multicolumn{2}{|c|}{$\begin{array}{l}\text { Municipality characteristics: } \\
\text { political factors }\end{array}$}} \\
\hline University & $4.60(3.28-6.46)^{*}$ & & \\
\hline Employment & & \multicolumn{2}{|l|}{ Largest party } \\
\hline Employed & $1.01(0.73-1.42)$ & Socialists (PvdA) & $0.84(0.59-1.19)$ \\
\hline Unemployed & 1.00 & Conservatives (CDA) & 1.00 \\
\hline Retired & $1.07(0.80-1.44)$ & Liberals (VVD) & $0.96(0.46-2.02)$ \\
\hline Income & & Socialists/conservative (SP) & $0.67(0.41-1.10)$ \\
\hline$<€ 1400$ & 1.00 & Local party & $0.90(0.67-1.21)$ \\
\hline$€ 1400-€ 1900$ & $1.15(0.93-1.41)$ & Liberal/socialist & $1.54(0.95-2.48)$ \\
\hline$€ 1900-€ 2500$ & $1.33(1.06-1.70)^{*}$ & & \\
\hline$>€ 2500$ & $1.06(0.80-1.41)$ & \multicolumn{2}{|l|}{ Alderman } \\
\hline General health & & Socialists (PvdA) & $0.85(0.66-1.10)$ \\
\hline Excellent & $0.93(0.74-1.17)$ & Conservatives (CDA) & 1.00 \\
\hline Good & 1.00 & Green party/liberal (GroenLinks) & $0.85(0.64-1.13)$ \\
\hline Poor & $1.31(1.08-1.61)^{*}$ & Socialists/conservative (SP) & $1.01(0.75-1.36)$ \\
\hline Mental health & & Local party & $0.92(0.64-1.32)$ \\
\hline Excellent & $1.16(0.97-1.39)$ & Liberal/socialist & $0.51(0.32-0.84) *$ \\
\hline Good & 1.00 & & \\
\hline Poor & $0.99(0.69-1.42)$ & & \\
\hline & Variatiol & percentage of citizens in municipa & ies: $27.3 \%-36.1 \%$ \\
\hline
\end{tabular}

Note: *Significant at the 0.05 level. 
Hoff, J., Cardol, M., Friele, R. Why does citizens' knowledge of new policy vary between municipalities? The case of the Social Support Act. Local Government Studies: 2013, 39(6), 816832

Table 3. Individual and municipal characteristics in relation to knowledge of voice within the Social Support Act (odds ratios (95\% confidence intervals); multivariate, multi-level regression models)

\begin{tabular}{|c|c|c|c|}
\hline \multicolumn{4}{|c|}{ Do you know how voice is organised? } \\
\hline $\begin{array}{l}\text { Participant } \\
\text { characteristics }\end{array}$ & Odds ratios & $\begin{array}{l}\text { Municipality characteristics: } \\
\text { structural factors }\end{array}$ & Odds ratios \\
\hline Gender & \multicolumn{3}{|c|}{ Disadvantaged neighbourhoods } \\
\hline Men & 1.00 & No & 1.00 \\
\hline Women & $0.97(0.80-1.19)$ & Yes & $1.03(0.69-1.53)$ \\
\hline Age & & \multicolumn{2}{|l|}{ Degree of urbanisation } \\
\hline $55-63$ & 1.00 & 1 (High urbanisation) & $0.65(0.27-1.52)$ \\
\hline $64-68$ & $1.10(0.81-1.50)$ & 2 & $0.83(0.61-1.12)$ \\
\hline $69-74$ & $0.97(0.70-1.36)$ & 3 & 1.00 \\
\hline$>74$ & $0.92(0.65-1.29)$ & 4 & $0.91(0.68-1.22)$ \\
\hline Education & & 5 (Low urbanisation) & $0.92(0.60-1.41)$ \\
\hline None/primary & 1.00 & & \\
\hline Secondary & $1.94(1.29-2.93) *$ & \multirow{2}{*}{\multicolumn{2}{|c|}{$\begin{array}{l}\text { Municipality characteristics: } \\
\text { political factors }\end{array}$}} \\
\hline University & $4.27(2.72-6.72)^{*}$ & & \\
\hline Employment & & Largest party & $1.08(0.72-1.60)$ \\
\hline Employed & $1.08(0.73-1.56)$ & Socialists (PvdA) & 1.00 \\
\hline Unemployed & 1.00 & Conservatives (CDA) & $2.09(1.01-4.33) *$ \\
\hline Retired & $0.84(0.60-1.18)$ & Liberals (VVD) & $1.45(0.83-2.56)$ \\
\hline Income & & Socialists/conservative (SP) & $1.39(1.00-1.94) *$ \\
\hline$<€ 1400$ & 1.00 & Local party & $2.39(1.47-3.88) *$ \\
\hline$€ 1400-€ 1900$ & $0.88(0.68-1.14)$ & Liberal/socialist & $1.08(0.72-1.60)$ \\
\hline$€ 1900-€ 2500$ & $1.00(0.77-1.31)$ & \multirow{2}{*}{\multicolumn{2}{|c|}{ Alderman }} \\
\hline$>€ 2500$ & $1.03(0.75-1.42)$ & & \\
\hline General health & & Socialists (PvdA) & $1.04(0.78-1.39)$ \\
\hline Excellent & $0.95(0.74-1.23)$ & Conservatives (CDA) & 1.00 \\
\hline Good & 1.00 & Green party/liberal (GroenLinks) & $0.75(0.53-1.06)$ \\
\hline Poor & $1.22(0.97-1.54)$ & Socialists/conservative (SP) & $0.76(0.54-1.08)$ \\
\hline Mental health & & Local party & $1.11(0.75-1.67)$ \\
\hline Excellent & $1.38(1.12-1.69)^{*}$ & Liberal/socialist & $0.77(0.44-1.33)$ \\
\hline Good & \multirow{3}{*}{\multicolumn{3}{|c|}{$\begin{array}{l}1.00 \\
0.56(0.34-0.92)^{*} \\
\text { Variation in percentage of citizens in municipalities: } 8.5 \%-18.1 \%\end{array}$}} \\
\hline Poor & & & \\
\hline & & & \\
\hline
\end{tabular}

Note: *Significant at the 0.05 level. 